University for Business and Technology in Kosovo

UBT Knowledge Center

UBT International Conference

2012 UBT International Conference

Nov 2nd, 9:00 AM - Nov 3rd, 5:00 PM

\title{
Kole Idromeno and the Neoclassical Architecture in Shkodra
}

Lida Miraj

Vitrina University, miraj.lida@gmail.com

Kujtime Barushi

EPOKA University, kujtimebarushi@gmai.com

Brixhita Deda

EPOKA University, dedabrixhita@yahoo.com

Follow this and additional works at: https://knowledgecenter.ubt-uni.net/conference

Part of the Architecture Commons

\section{Recommended Citation}

Miraj, Lida; Barushi, Kujtime; and Deda, Brixhita, "Kole Idromeno and the Neoclassical Architecture in Shkodra" (2012). UBT International Conference. 15.

https://knowledgecenter.ubt-uni.net/conference/2012/all-events/15

This Event is brought to you for free and open access by the Publication and Journals at UBT Knowledge Center. It has been accepted for inclusion in UBT International Conference by an authorized administrator of UBT Knowledge Center. For more information, please contact knowledge.center@ubt-uni.net. 


\title{
Kole Idromeno and the Neoclassical Architecture in Shkodra
}

\author{
Lida Miraj ${ }^{1}$, Kujtime Barushi ${ }^{2}$, and Brixhita Deda ${ }^{3}$, \\ ${ }^{1}$ Prof. Assoc. Dr. Lida Miraj, Vitrina University, \\ miraj.lida@gmail.com \\ ${ }^{2}$ Arch Kujtime Barushi, Epoka University \\ kujtimebarushi@gmai.com \\ ${ }^{1}$ Arch. Brixhita Deda, Epoka University, \\ dedabrixhita@yahoo.com
}

\begin{abstract}
This paper reveals the precious contribution of Kolë Idromeno, as a versatile artist, whose work and activity constitutes a great heritage for the Albanian National Culture. Among his donated skills in art, what mostly attracts is the ensemble of the neoclassical buildings he designed during the first decades of the last century. His architectural projects are defined as second category monuments and 'exhibited' along the museum streets protected by law. The research design makes use of different methods, as the fieldwork, data collection, and review of documents consisting in both qualitative and quantitative information. Qualitative and quantitative methods include basically these different sources of information: interviews with representative of public institutions, owners of villas designed from Kole Idromeno, review of documentary such as studies, documents and periodicals written during the last century, field works which include the survey and the drawing process of architectural features of the buildings, check and evidence of today preserved work of Idromeno on site. It was little studied Idromeno 's contribution in architecture. Our aim is to check out several villas in Shkodra designed by this artist-architect and present their detailed architectural draft, including their renovation or revitalization project.
\end{abstract}

Keywords: Kole Idromeno, Neoclassical Architecture, Shkodra , XX century, Cultural Heritage

\section{Kole Idromeno - a vers atile artist}

The life and the rich and varied activity of the artist Kole Idromeno covers the entire main period of Albanian National Renaissance until the Independence Day, in November, $28^{\text {th }} 1912$ and all the subsequent period during the creation of the Albanian State and Albanian Kingdom. He strongly connected his artistic creativity with the important event to the important north Albanian city, Shkodra, and from this point of view, his historical work as a painter, sculptor, photographer, musician, scene-painter, and mask-maker, has not only a high professional level, but everything he created is based on the patriotism and social-democratic ideas.

Kole Idromeno was born in Shkodra on 15 August 1860 and raised in a relatively civilized and developed environment for the time being. In XIX century, Shkodra was one of the main important cities of our country, regarding the economic, social and cultural aspect, for the splendor of its significance as a center of Villayet and for the greater liaison role played in trade with Adriatic and Mediterranean Basin countries.

After the importance gained as a center of Northern Albania as well as during the Patriarchy period 1757-1831, Shkodra was progressively developing. One of the first catalysts of capitalist development in our country was initiated in this period. The commercial exchange with different agricultural products and livestock, silk and leather, wool, exploitation of forests, as well as our handicrafts products yielded good incomes. The rich citizen class especially bourgeoisie as a new class, in continuous contact with European bourgeoisie began to make a sophisticated and civilized life according to the needs of the period they lived. 
In the family of Arsen Idromeno flourished the great joy and pleasure of the newborn male child Kole Idromeno. Arsen was a carpenter and autodidact, so Kole took after his father the talent for design. Since the infancy he displayed the propensity for simple drawings. During the primary school, he took lessons in Italian language, but on the other hand he was given the opportunity to learn his native language. The very first drawing lessons were taken from clergy (1867 - 71) and then (1871-74) followed by Pjeter Marubi, a known painter and photographer with the assistance of which started the first portraits.

In 1875, his father, Arsen Idromeno decided to send his son in Venice to attend the Academy of Fine Arts. In Albania, Kole Idromeno used to create independently, satisfying his desires, while at the Academy Arts, the methodology of learning was different. The assignment given in the program appeared very simple for Idromeno's skills, but even for a tiny, non considerable mistake, students were obliged to repeat the work, not once but several times. He could hardly stand and get used with this discipline and rigid rules of the academy that prohibited his freedom in art. Unfortunately, despite the sacrifices that Idromeno was ready to overtake, this kind of working and learning approach discouraged and disappointed his expectations. The feeling of superiority that his professors showed ironically, made him feel not appreciated and comfortable with the staff over there, as much as he deserved. Although Kole Idromeno had no intention of staying in Venice, the familiarization with a Venetian painter did change his mind. He worked for approximately two years as assistant and then as collaborator due to his admirable skills. There he was closely acquainted with the works of Carlo Crivelli, Andrea Mantegna, Giovanni e Gentile Bellini, Lazzaro Bastiani. Thanks to the help and guidance of this experienced painter, Idromeno worked hard and knew how to benefit from master works of art.

Once finished the studies, in 1878 Idromeno was back in his beloved city with the huge desire to contribute there. He was involved in the patriotic movement and brought the western culture in architecture, painting etc. As a man of social progress, he was the first to bring in Albania in 1912 and cinema and experimented to cover the profession of the cinematographer.

Furthermore, Idromeno built a simple brick and Marseille tile factory, designed the building of the power plant in Shkoder and the shoe factory. He designed and was the team leader in the construction of more than 60 private and public buildings in the city and its villages.

As a musician he took part in the first country music band (Shkoder 1878), as a photographer of the city he served for over 40 years without interruption, as a scene-painter he was noted for careful artistic work helping amateur theater groups of Shkodra, as a talented mask maker he prepared for many years masks for the Carnival's fests that were and still celebrated in Shkodra. Actually the name of Kole Idromeno is always connected with paintings, because his main master and talent exploded in the art of painting. He was a good sculptor as well, owning the skill and ability to sculpt wood, stone, marble, as well as to generate sculptures in plaster, cement and other materials. The only appreciated memory left from his work as a scene -painter, decorator is a scene, scenic background, named as 'Salloni me kolona' (The Hall with Pillars) and prepared over the years 1922-1924, probably for any classical play in the theater. It has been preserved in the theater 'Migjeni' as a precious object in the history of this theater. The huge, slat wall sized scene shows incredibly well the perspective and light in such a way that it looks like you are in a real salon. For the major part of interpretations or plays in the theater he realized the effect on the viewer, the historical background of events providing educational value and interest to the public. Meanwhile, he revealed his skills as master in the preparation of armor, helmets, hoes, spears, flags and other materials used in drama combat scenes.

In Shkodra, since the late eighteenth century, there existed the tradition to celebrate popular carnivals in February. In 1911, Kola organized the carnival with a rich program. In collaboration with famous comics of the city, he was not limited just in the design and production of beautiful masks but wrote also dialogue texts and poems programmed in these series of live performances in the city too. While the carnivals of the 1920 s until 1924 were guided generally by current 
political events, subsequent carnivals treated mainly social concerns and issues. The decoration of carnival carriages, wheels and other means gave the caravan of masked faces a rare charm and a more cheerful atmosphere.

By sticking to the aesthetic principle for realistic reflection of life, with these works, he further defines his style, forms his personality as an artist exerting a positive influence in the constellation of contemporary painters and younger generations of artists whom had left for the relay.

The relationship with ordinary people throughout life gave him the appropriate inspiration for his creative work regarding the subjects and realizations. His works in picture preserved until today include landscape, tableaus and especially portraits, in which the artist excelled as a talented colourist. Generally his works are conceived simple, clear and tasteful. His realistic art was inspired by a popular spirit and had a national character which gave his abundant creativeness indisputable ideological and artistic values.

During his life, he participated with his pictures in The Gallery of Arts of Shkodra in 1923, in that of Tirana in 1931 and in six international exhibitions abroad in Wien, Budapest, Rome, Bari, and New York. It is a known fact that he executed some paintings for the institutions of the cult on orders, especially during the end of the XVIII century, but most of his works in painting belong to unreligious tableaus. Idromeno is considered the founder of the Shkodran School of realistic painters of Albanian National Renaissance.

He has also referred vaguely social topics, such as 'Motra Tone'(Sister tone) ,Gjakmarrja'( The revenge), 'Portret fshatari' (Peasant's Portrait), 'Portret Muratori'( Portrait of a Mason). 'Motra Tone' (1883), is considered the first psychological and social portrait in the Albania realistic painting of the national Renaissance and one of the masterpieces of the painter. This portrait is one of the finest creations as it holds variation of line and richness of colour.

During the summer of 1924, the time of the triumph of the June Democratic Revolution, Kole Idromeno completed one of the masterpieces, the tableau 'Dasma Shkodrane' ( Shkodran Wedding), which like many of his creations has profuse light, great liveliness, and movement. The technique of painting directly in the sun-light has been successfully applied. Though a traditional ceremony, the work is entirely devoid of any religious note.

Thousands of photos from Idromeno, a gallery of portraits or pictures of different people and professions, Albanian landscape and his hometown came out from his fund. His aesthetic worldview was realistic. He made a valuable contribution to the works of art in the new national culture. In the focus of his photography, he presents the simple man, young or elder man, children and women, usually dressed in traditional folk costumes. It is interesting the fact that in the eighteenth century, in international publications in Paris, London, Istanbul and elsewhere, Idromeno is displayed as the first photographer in Shkoder, even before his professor Pjeter Marubi. As a photographer he has a rich ensemble of work, and advanced technique for that period.

Figure 1: "Motra Tone", "Sister Tone"

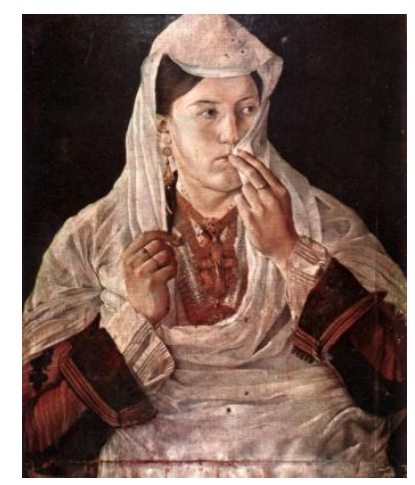


Figure 2 : A carnival group, 1929, prepared by Idromeno

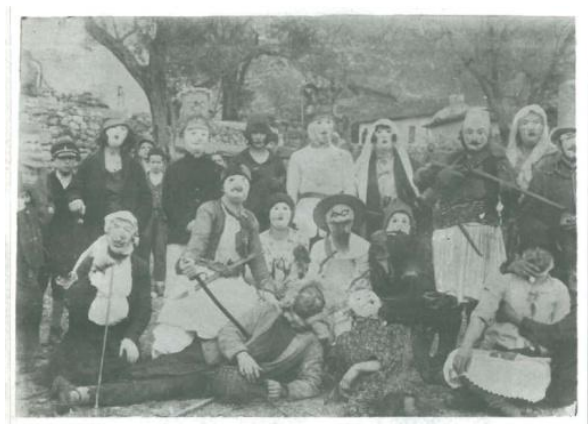

Figure 4 : Dasma Shkodrane", (Shkodran Wedding)

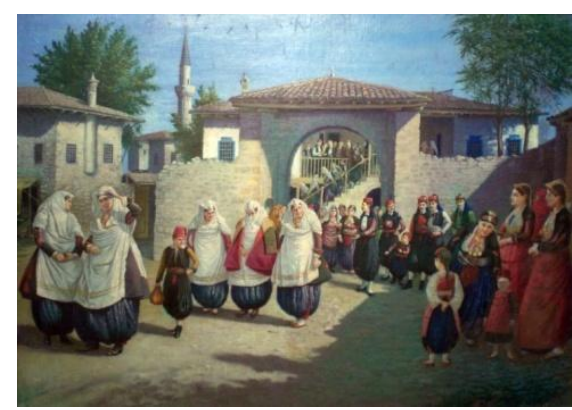

Figure 6 : Portrait of Sister Tone

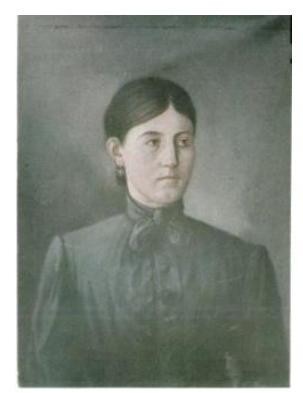

Figure 3: Wind orchestra of Shkodra in 1878 , part of which was also

KoleIdromeno (line second, third from left)

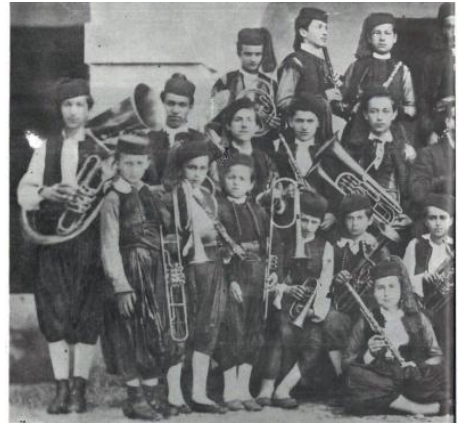

Figure 5: "Saloni me kolona" drawn by Idromeno

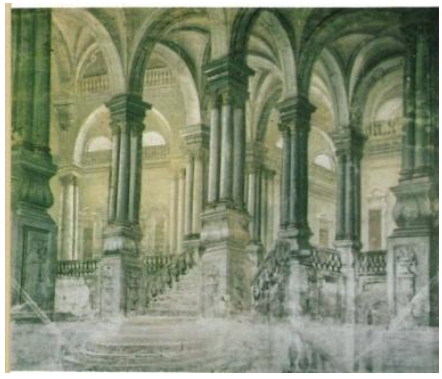

Figure 8: Autoportrait

Figure 7 :Arsen Idromeno

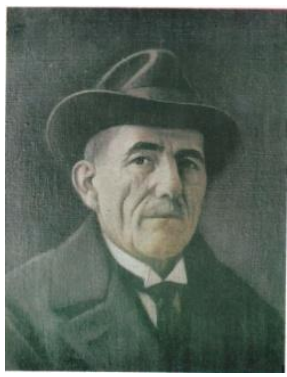




\section{Idromeno's architectural contribution}

All above are facts introducing the complex personality of Kol Idromeno, but the focus of this paper lays on his contribution as an architect, as one of the firsts Albanian Architects in the period before and after the Independence Day. Shkodra in this period began a new life; national schools were opened, cultural societies were refreshed and established new societies, Albanian language became compulsory in administration etc. To the economic, commercial and cultural development of the city would respond also the new constructions in terms of the overall urban planning and separate private and public buildings.

A major contribution in this regard has given also Kole Idromeno. His first teacher was Pjeter Marubi. His father, Arsen Idromeno, known in Shkoder as a self-taught engineer, which practiced successfully the profession, was his teacher too. Idromeno's first completed works were not scarce even before 1912. The desire for better, strong and beautiful buildings, breaded to Shkodra citizens with better economical outcomes, especially after the earthquake of 1905, which leveled a good part of Shkodra, in particular the buildings made of Kir sand stone. Since 1905 , Kole Idromeno had started the successful implementation of its projects in construction and was notable for a very careful job with quality.

The dream of this artist and architect was to transform Shkodra into a modern city, like many famous Mediterranean cities. More than 60 main private and public buildings are designed and implemented by him in the city of Shkodra, giving a clear result of his tireless work since the beginning of last century until he died Idromeno introduced decorative painting and sculpture with bas-relief, combined with harmony genres of art with architecture.

He studied the Albanian traditional city's buildings and the architectural heritage in general and went into details in its positive functional features, especially for other environments and interiors. He knew the influence of Ottoman Architecture in the villas of Shkodra and other Albanian cities, such as Berati or Gjirokastra and wanted to introduce another style, with western inspiration. It was the period of Neoclassical Architecture, produced by the neoclassical movement that began in the mid-18th century, manifested both in its details as a reaction against the Rococo style of naturalistic ornament, and in its architectural formulas as an outgrowth of some classicizing features of Late Baroque. Idromeno was in touch with the new coming style where its purest form was a style principally derived from the architecture of Classical Greece and Rome and the architecture of the Italian architect Andrea Palladio. In form, neoclassical architecture emphasizes the wall rather than chiaroscuro and maintains separate identities to each of its

parts. In the late 1800 s and early 1900s, ancient Greek and Roman ideas were combined with balustrades, balconies, and lavish decoration. In Albania neoclassical architecture was not against Rococo and Late Baroque, because they didn't exist.

In Albania, Neoclassicism covers a movement connected with the western influence, based on Palladio' style which came as a reaction against the influence of Ottoman style in architecture. The architectural details and motifs became gradually calmer and simpler to approach the classical ideas and the return to nature fostered the emergence of a new architectural idiom. In this idiom certain features recur constantly: clear-cut lines, monochrome surfaces, simple masses, antique archetypes (which are tholos, temple, peripteros, pantheon), elementary geometrical forms (which are cube, sphere, pyramid, cylinder), contrasts emphasized by light and shade, regular colonnades and porticos contrasting with great bare walls of simplicity, and finally cupolas and barrel-vaults. 
On the basis of his studies Kole Idromeno designed different projects according to the spatial position of the house, to be built in architectural ensemble with other buildings.

He has realized many other projects for the renovation of old types of houses. Idromeno, as an architect and urban planner, surpassed the dwelling limit creativity. He aimed at creating ensembles with architectural and urban value for the city. Two main characteristic streets in the center of Shkodra, the street "Course of December $13^{\text {th }}$ " and the street "Branko Kadija", now preserved as "Museum Streets", in their compositional urban-architectural entirety were Kole Idromeno's work.

Kole Idromen has also other works in the city, villas in the neighborhood Parruce, Dergut, the electricity plant of the city, the old leather factory, Shiroka's villa, the coffee bar "Adriatic", the coffee bar "Park", the former cinema "Rozafa", the Bank of State, etc. He also took care for the construction of social and economic buildings, for rest and recreation facilities, according to a regulatory plan, having the Course of December $13^{\text {th }}$ in the center. He designed sidewalks, drainage channels, placed the lights and what is the most important: designed the building facades rich of ornamental sculpture and balconies. The upper part of the buildings usually were designed for living rooms, while the lower were designed for stores, in order to solve the problem of the concentration of economic activity in the city center.

In his first realized projects we have the building of the club "Albanian language" in 1908 (Mazi house) which he designed as a meeting and performance place in the lower floor, and living in the upper. Precisely in this building his first society "Rozafa" performed its activity. Besides the beautiful houses built in the main street of the city, the contribution of the architect includes many private houses and 'Dugat e reja' as well.

In 1928 he designed the power plant. An Italian capitalist society (SESA) received concessions from anti-popular regime and built this plant to obtain profits. For this purpose an Italian engineer came in Shkodra, but the greater effort in projecting and construction application was made from our engineer.

As a man addicted to social progress and economic development of the city, Kole Idromeno tried to initiate industrial, social and cultural buildings, but tools and opportunities were scarce. Shiroka's villa, built in 1925-1926, was appointed to an engineer from Tirana, but the revision of the project and all the work for its implementation was entrusted to Kole Idromeno. Its construction was really a great success of this architect. But ruling classes did not appreciate the work of this talented man. Even when the villa was built, Kola was not invited in the inauguration day.

Kole Idromeno with all his efforts managed to design and implement in construction a Leather factory (today's shoes Factory), while a brewery that started as a project in 1927, was never completed due to lack of funds, because his project was made for a genuine industrial building with considerable capacity.

He paid attention to building materials as he was a master in implementing his projects in construction. He used mountain stones; lime seasoned and decided the site where they should be taken. Kola was the first to use very early the ferro-cement, prepared carefully by mixing scientific recipes.

He had set up a small factory of bricks and Marseille tiles for building needs. Kole Idromeno was a man of many crafts. In his metal working plant, he prepared iron balustrades and other parts of iron or brass, which sought a better technical work. He worked hard for iron banister and beaten baluster in his plant, while as a mechanic he made hammers, pliers, bars and simple door locks.

He was also interested for the urban planning project of the city, for a general regulatory plan. It is known that after the Declaration of Independence, favorable conditions were created for new, better constructions and development of a regulatory plan for the city. Unfortunately, the occurrence of the First World War prevented the progress in some sectors of life. 
Figure 9 : Villa

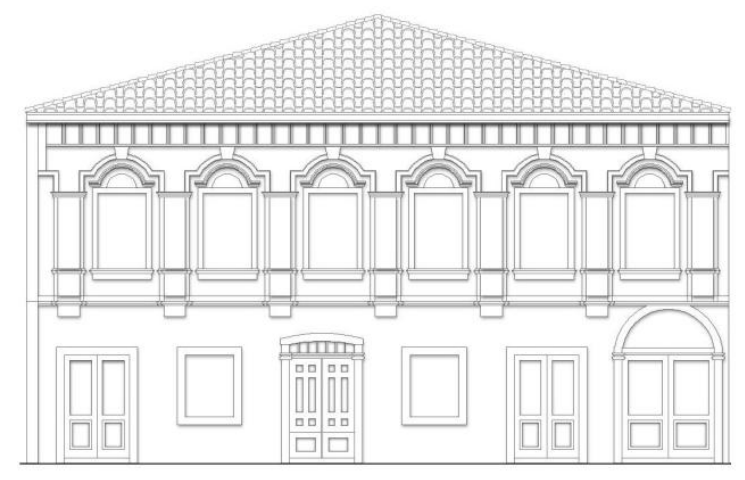

Figure 11 : Idromeno's house

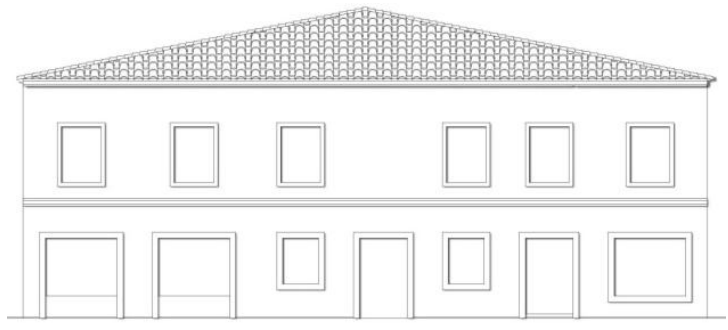

Figure 12: "Kafja e Madhe"
Figure 10 : Clock's tower

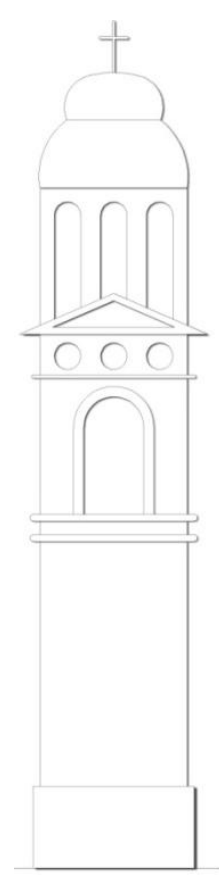

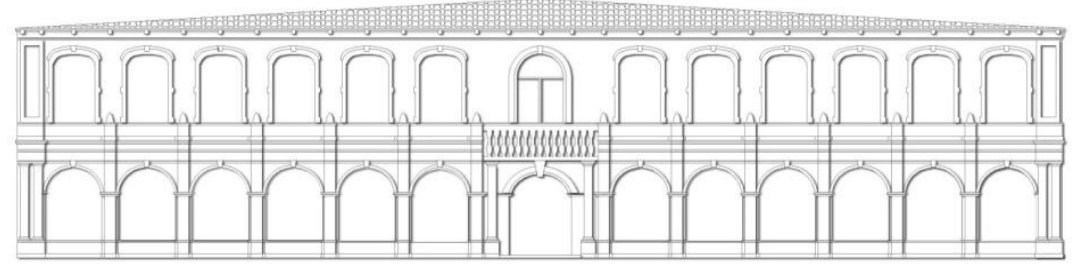

Figure 13: Shopping retail Front view of the villa

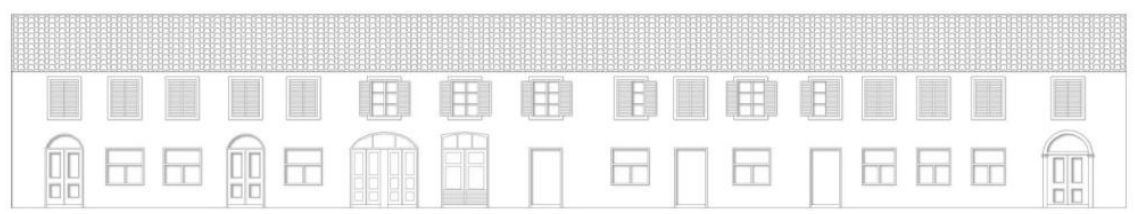




\section{Comparative analysis of architectural housing topologies in Shkodra}

During the end of Ottoman rule, strong stone buildings began to develop especially in the early nineteenth century. Shkodra's structure was immediately characterized by a strong division of Muslim neighbourhoods (which comprised the majority) and catholic neighbourhoods.

The most characteristic feature of Muslim neighbourhood are the large houses of Ottoman Balkan style, with spacious yards and gardens, typically surrounded by high walls made of local stones. Their system of roads is branched and often they end up in alleys or dead end streets.

While the catholic neighbourhoods e.g. Gjuhadol, due to different social- economic conditions were presented differently. These neighbourhoods have transverse road and small houses, often two storeys high. This gives to the neighbourhood a civic character in comparison to others, therefore this area is declared a cultural monument and from that time there have been undertaken restoration works of buildings that contain architectural values.

Figure 14: 'Oso Kuka' Museum, ottoman influence

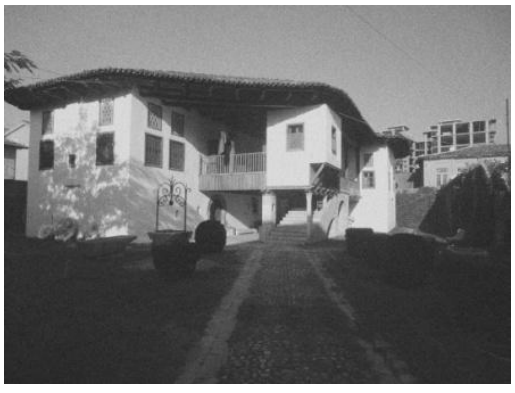

Figure 15: Neoclassical buildings

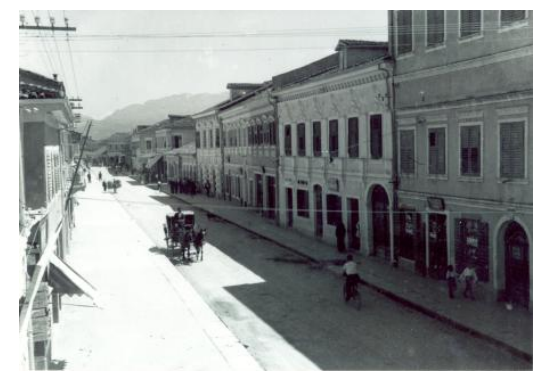

Case studies

Constructions, carried out in the city of Shkodra over forty years as an architect are still preserved today. The buildings on the main road "Branko Kadija" undertook a restoration during 1981. A careful inventory, survey and study their and would reveal our traditions preserved and developed by him, because in his projects and applications Idromeno showed the basic characteristics of Albanian citizen housing with a combination of styles. Especially the facades of these buildings are rich with polygonal frames, borders and ornaments set on doors and windows. He adorned also balconies and surrounded them with iron balustrades, louvre windows etc. These buildings interior have halls, foregoing beautiful stairs with balustrades, large bright rooms, occasionally painted ceilings and beautiful chimney. In architecture and decoration of facades seem to influence the most advanced cities of the Mediterranean. In one of the houses he has introduced into the walls, like the common builders, sash of trees to be protected from earthquakes, but in many cases as an anti-seismic measure he used concrete layers. In order to illustrate these features, this paper includes the case studies below, in their existing situation and the proposals for conservation and restoration. The first villa project is Dr. Prela's House, and the second is one of the most elaborated and ornamented villa ever designed by Idromeno, Cobaj's House. 


\subsection{Dr. Prela's House}

\subsubsection{Existing Situation}

- The walls are full of moisture.

- The window bars are almost completely rusted.

- Humidity caused a great amount of mold.

- Stained humidity near the windows and the gutter

\subsubsection{Proposals for Conservation and Restoration}

- House construction is based on load- bearing wall. Walls are durable and stable due to their structure, so the villa doesn't need constructive reinforcements. To remove humidity it is important to verify its cause. If the humidity is as an outside phenomenon, because of the age, we remove the plaster under 'sicknesses' and then, after doing analysis how the plaster was made, put another plaster composed with the same components. If the humidity is in the ground floor, is important to clean around foundations and to do their hydro isolation.

- In order to remove stains caused by the humidity we will interfere with toothbrushes from sorghum.

- Where spots appear severe, they can be treated by washing.

- Restoring all the damaged parts.

- Painting with the original color each element of the facade.

Figure 16 : Front view of the villa

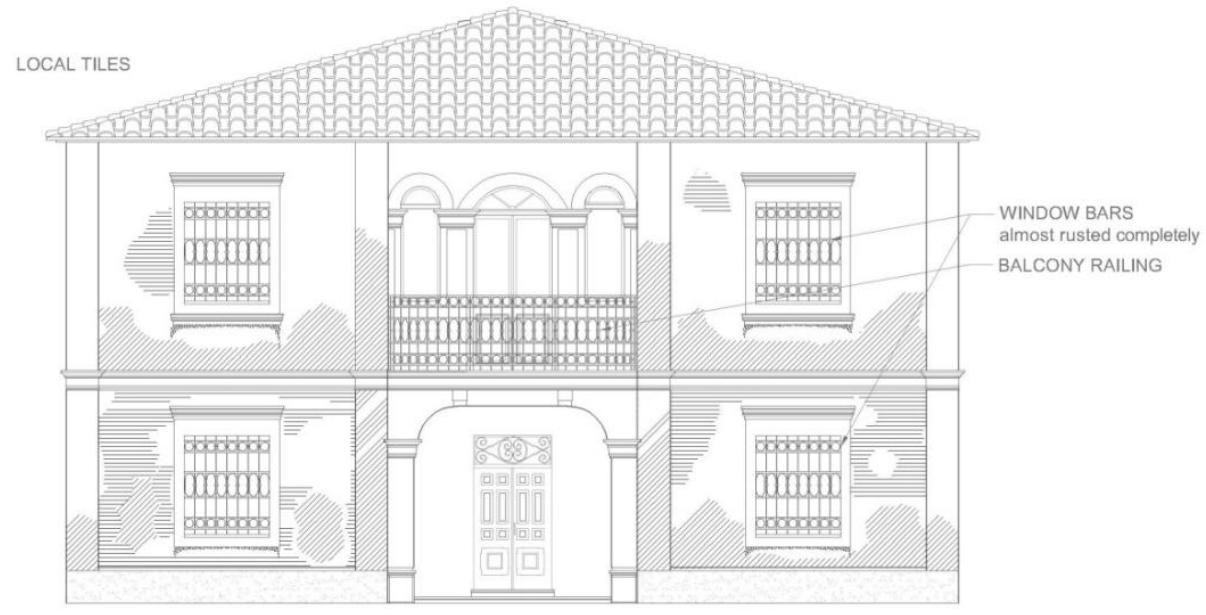

Figure 17 : Ground floor

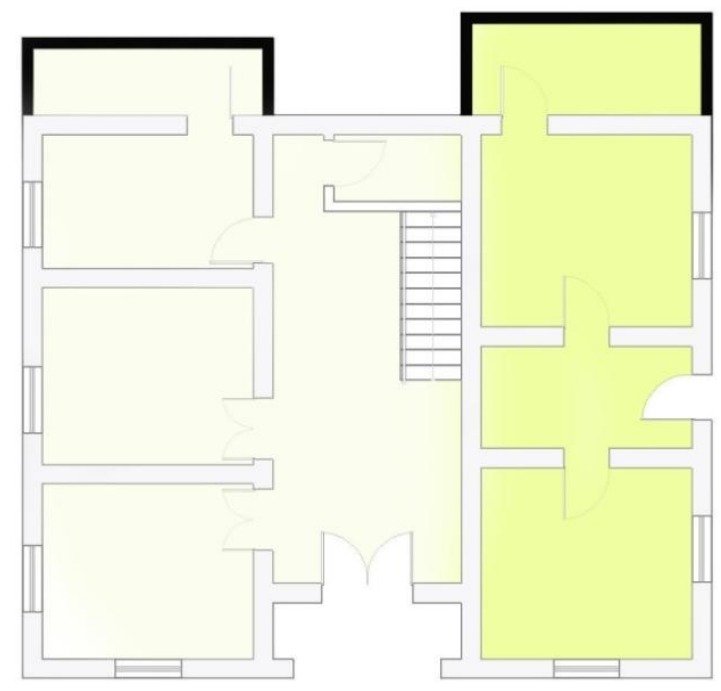


Figure 18 : First floor

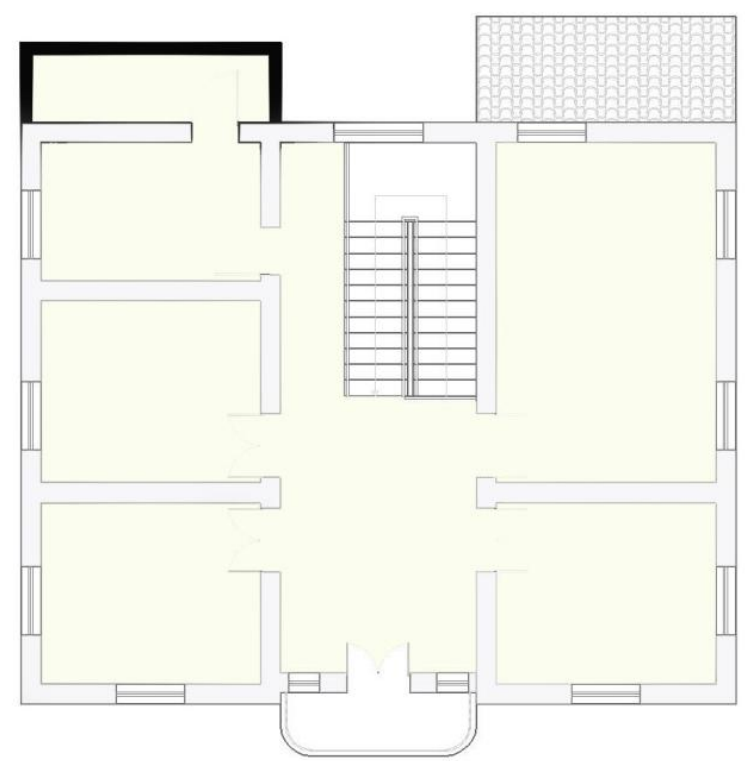

Figure 19: Front view of the villa

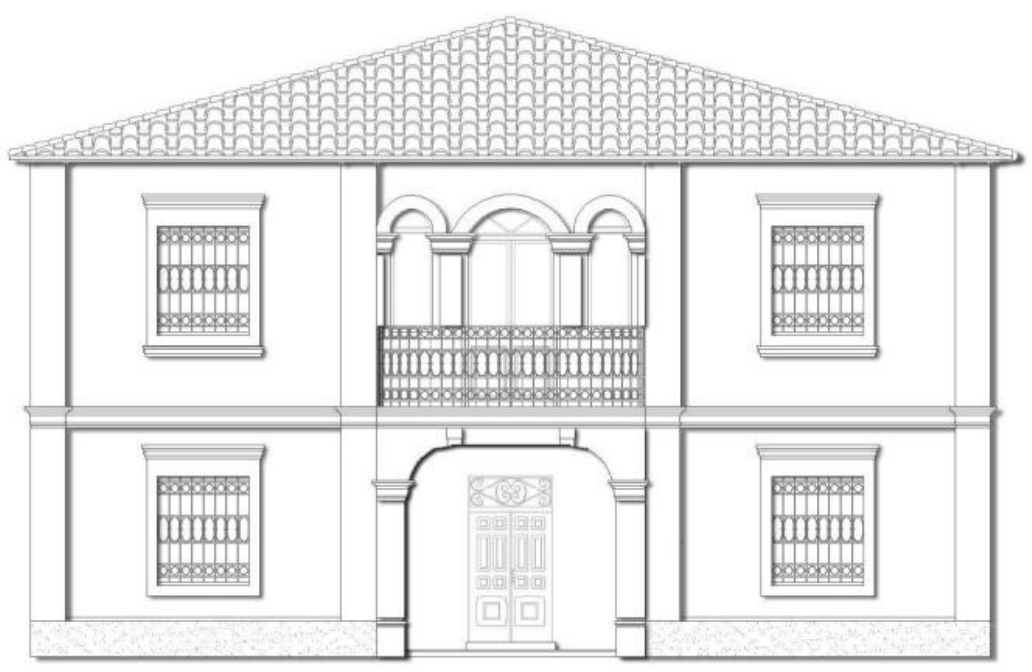


Figure 20 : Back view of Dr. Prela's villa

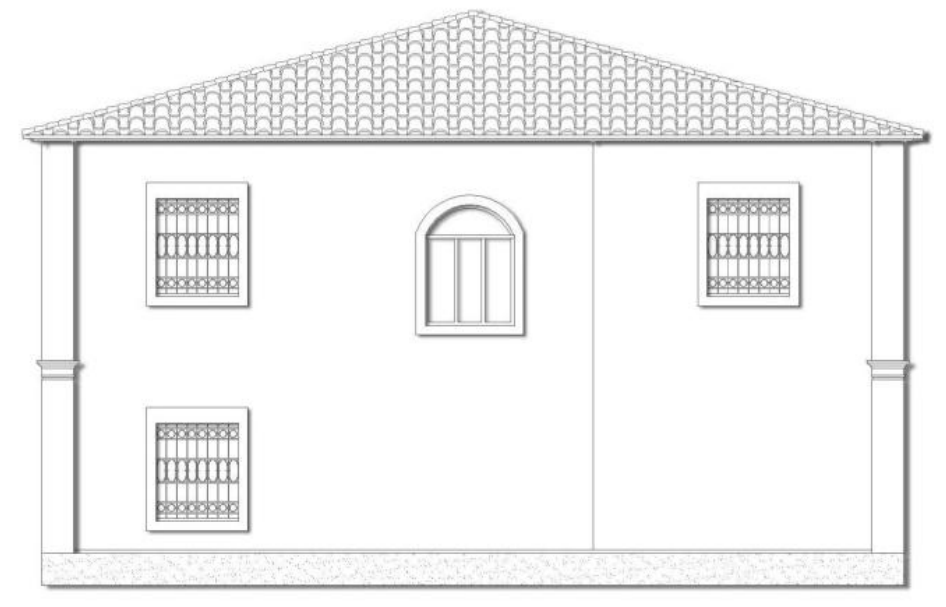

Figure 21 : Door and window detail
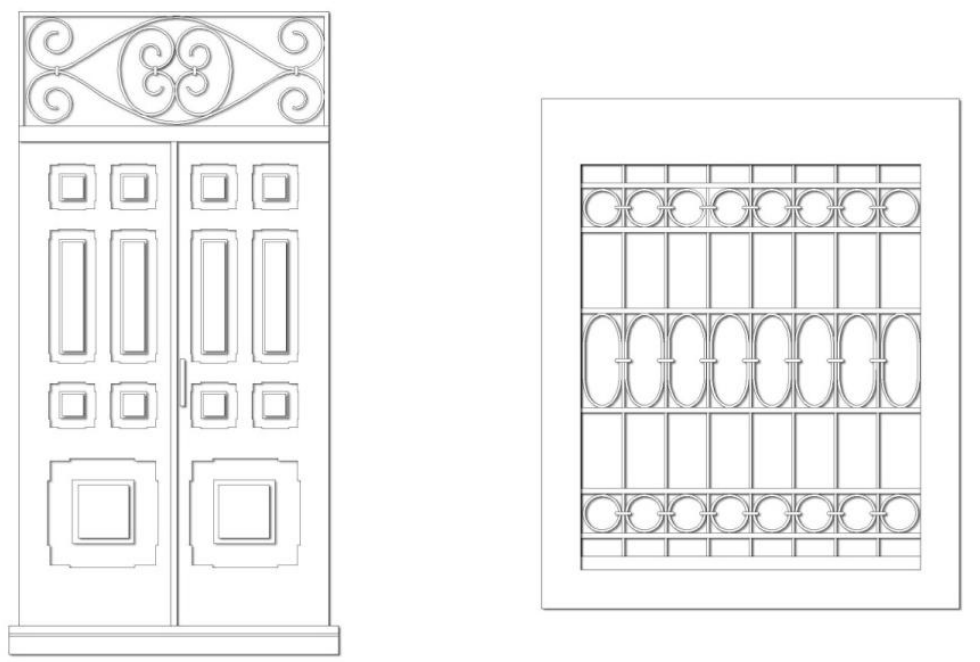
Figure 22 : Door and window detail

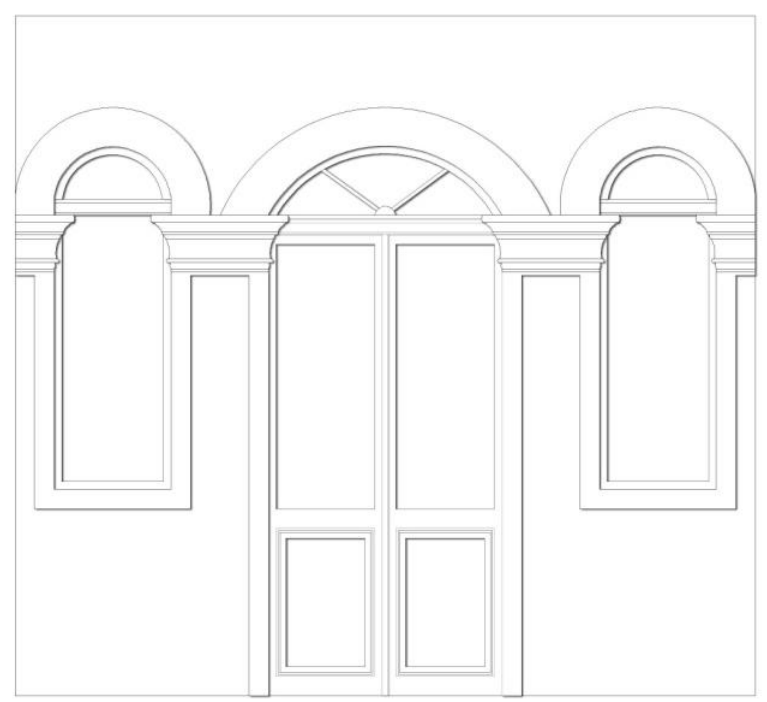

\subsection{Cobaj's House}

\subsubsection{Existing situation}

The two- storey house is surrounded by a stone wall which creates a small yard. The ground floor plan divides four living spaces and a spacious hall in the middle. The greatest damage is in the facade, as a result of exposure to climatic conditions. Stairs and floor tiles are the most decorative part of the interior.

\subsubsection{Proposals for Conservation and Restoration}

The concept of restoration is that of minimal intervention in the villa's appearance which remained untouched; it supposes

- Preservation of every detail of the facade as it was initially designed and built.

- Cleaning of facades.

- Adjustment of damaged parts

- Painting of walls with the original colours.

- Restoration of the ceiling in wood, and not in plastic.

- Painting of doors and windows in green color, as they previously used to be.

- Replacement of aluminum window frames with wood, preserving not only the construction material but also design.

- The informal adding's must be removed.

- Careful restoration and preservation of the original decor of its unique exteriors

Since there is no structural problem, only superficial restorations must be done, such as: Plastering the inner walls, after cleaning the humidity problems in some parts of the walls. From the functional point of view, we propose to add a bathroom designed in the end of the salon, and an exit door to the garden. The rooms are used for living, kitchen, studio, and guest room for special events. While the first floor includes a bathroom for the inhabitants, two bedrooms for children and grandparents, one matrimonial bedroom with its bathroom and a room for rest. 
Figure 23 : Front view of Cobaj's House

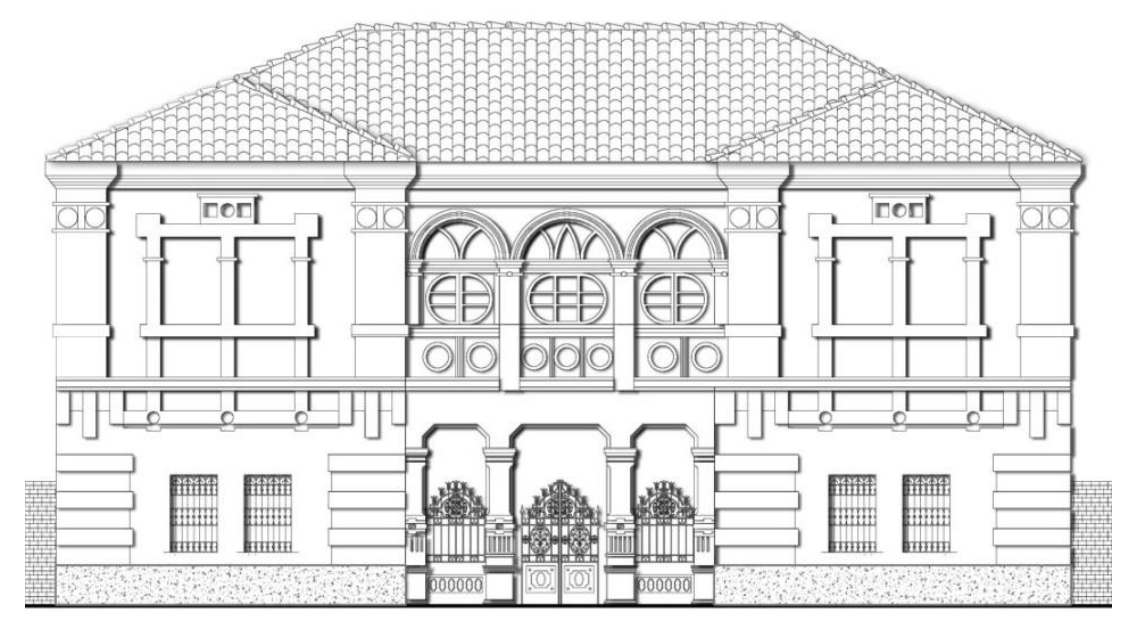

Figure 24 : Rear façade

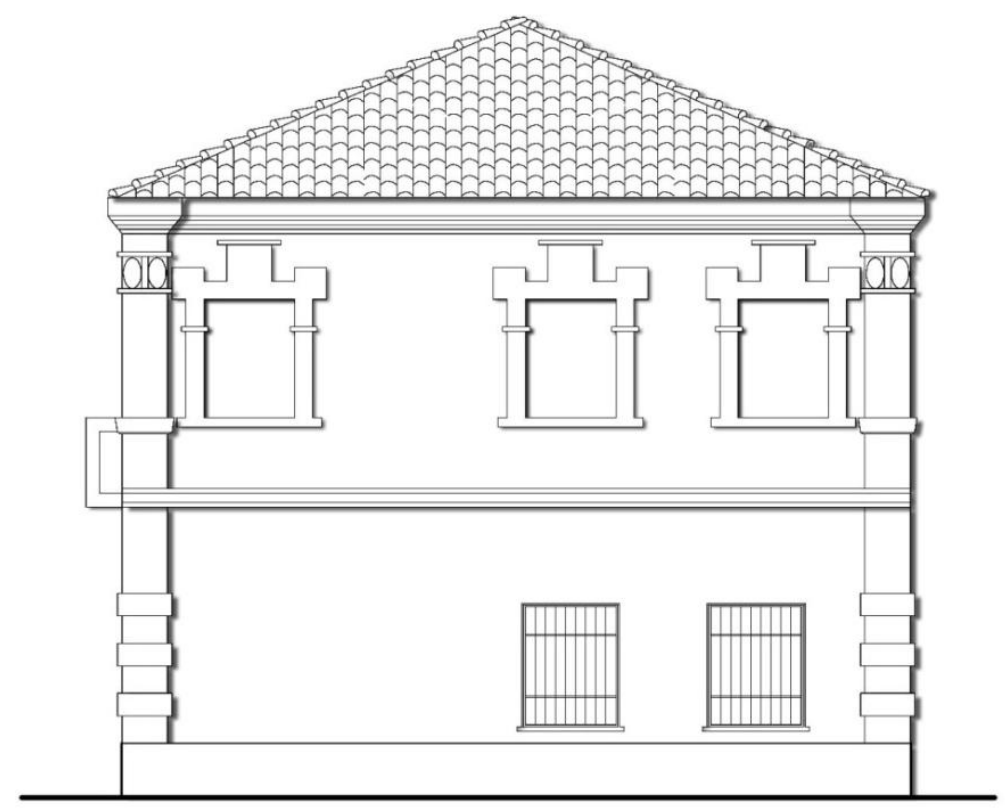


Figure 25 : Existing ground floor plan

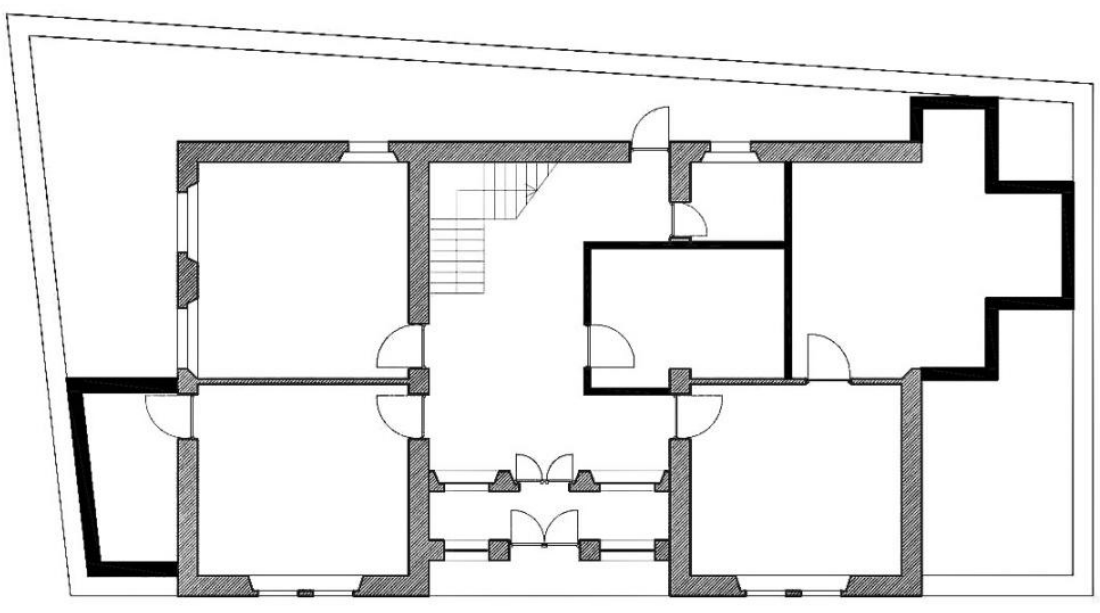

Figure 26 : Ground floor plan according to Idromeno design

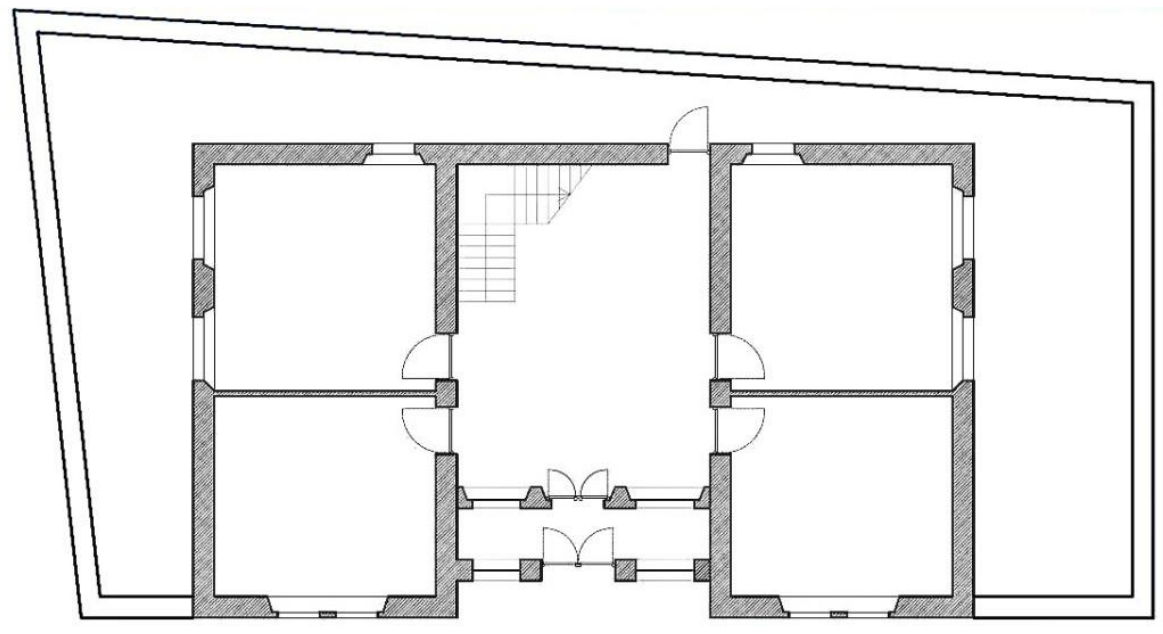


Figure 27: Restoration proposal for ground floor plan

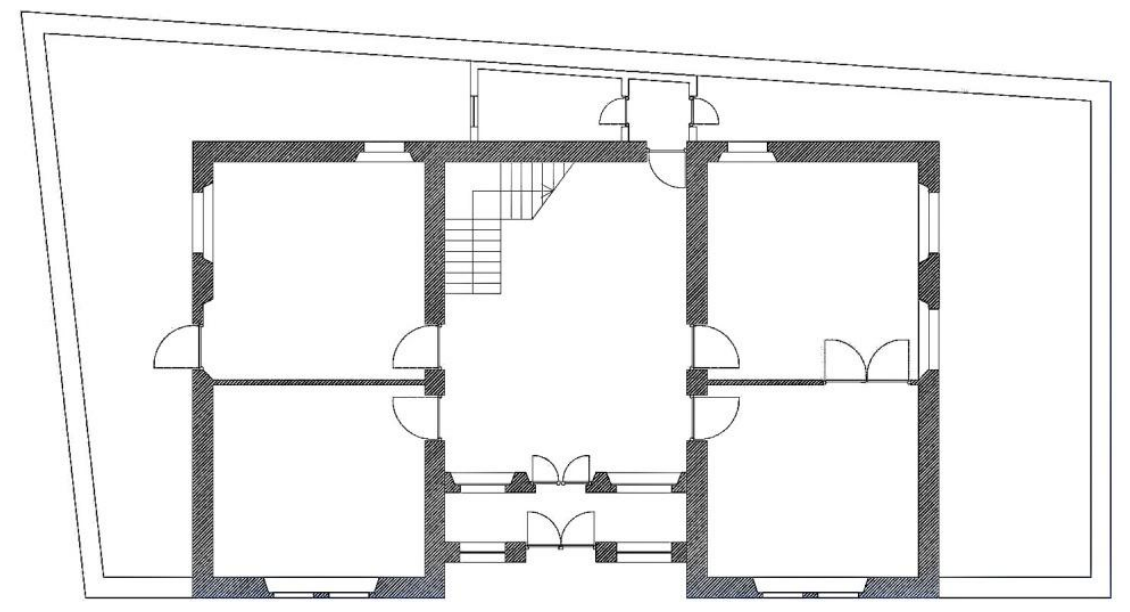

Figure 28 : Restoration proposal for first floor plan

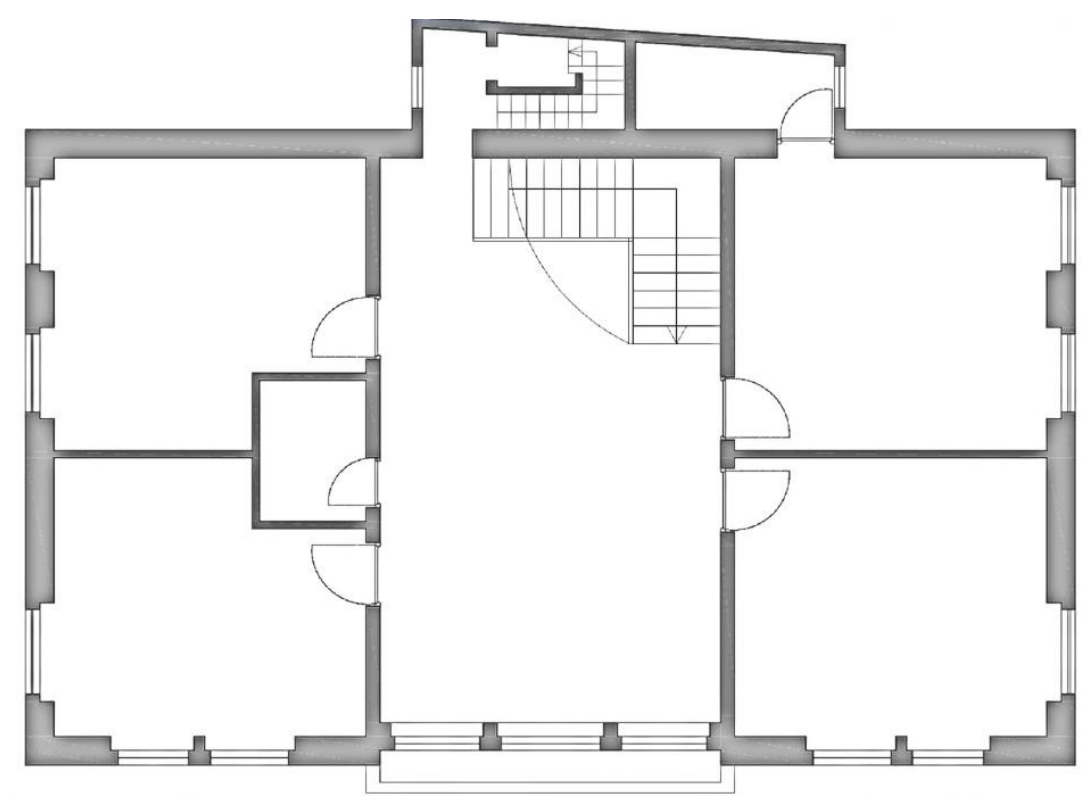


Figure 29: Stair, Door and Window detail

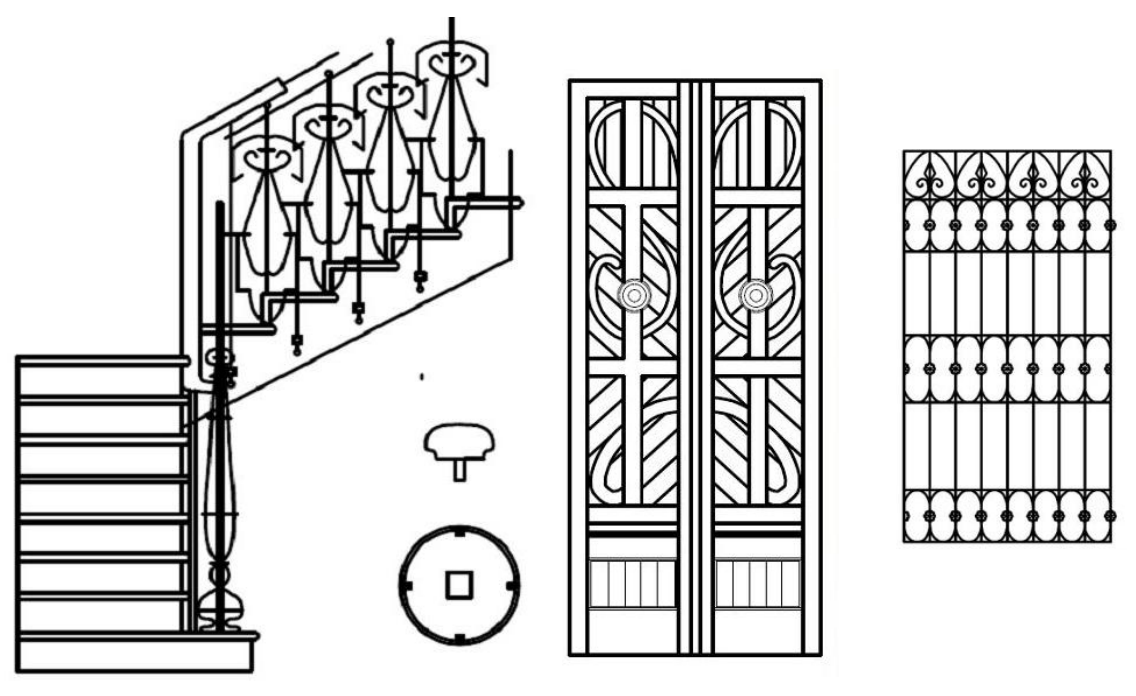

Figure 30 : Main entrance detail

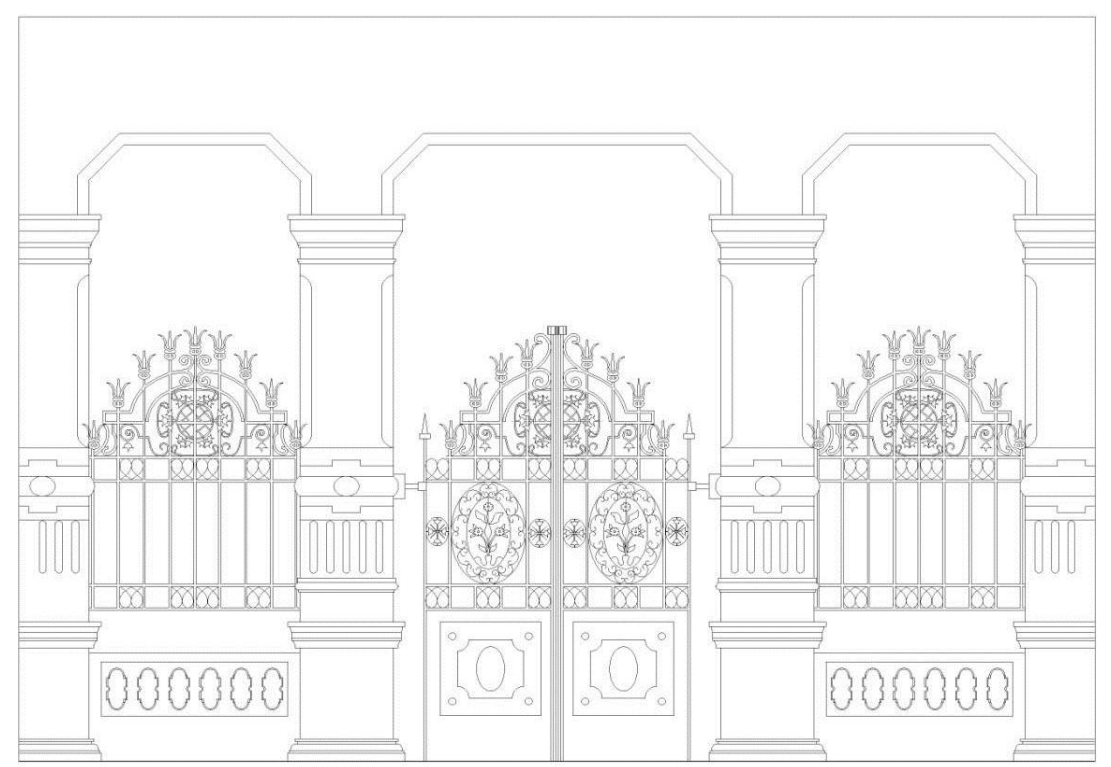


Figure 31 : Window and balcony detail

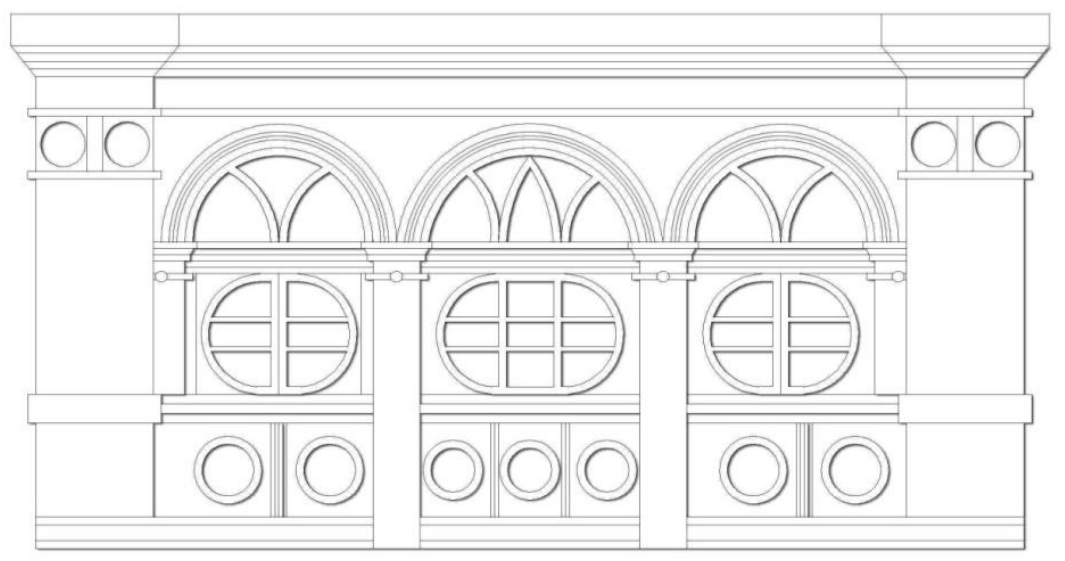

\section{Conclusions}

This study exhibits the flexible personality of Kole Idromeno as an artist of many crafts and design skills. In recognition to the treasured and appreciated life of this patriot artist and social activist, and his rich creativity of a high artistic spirit, the Presidium of the National Assembly on 2 June 1984, granted Kole Arsen Idromeno the award "Piktor i Popullit "with the motivation: "For outstanding merit in the field of art as a painter, sculptor, architect, scenepainter and talented photographer and for the realization of high-level artistic works with secular content." This Talented artist is a worthy representative of the Albanian traditional art.

Throughout the analysis of his overall involvement on several genres of art, we focused on his activity and contribution in the architectural aspect in the city of Shkodra. Mostly the villas, designed by Idromeno nowadays are preserved in "museum" streets, in their compositional urban-architectural entirety as cultural monuments of second category. On the focus there are two case studies: (1) his first villa project and (2) one of the most elaborated villas of Idromeno. The analysis includes current situation and restoration proposal. The restoration consists of the protection of the architectural features of building facades, as well as the revitalization of the building performance too.

We will finish a complete work on the activity of Kol Idromeno as an architect in the period of the Independence of the country and will propose an architectural price on his name for Albanian Architects. 


\section{References}

Prendushi, M. ( 1984) Kol Idromeno, jeta dhe veprat, 8 Nentori, Tirana

Shllaku L.(1962) Kole idromeno dhe krijimtaria e tij, Nentori vol.7, p.135

Zanetti G. ( 1850) Studiarchittectonico-ornamentali, St. Ant., Venezia

Gurashi K. (1963) Te dhena biografike mbi disa kengetare popullore', Shkodra 1963,pp. 197; (1964) Shkodra 1964 ,pp. 161.

Shllaku L. (1962) et. al. , Nentori, Vol. 7, Tirana, pp.135Vlashi Gj. (1979) Kole Idromeno per teatrin , Drita, Tirana, pp.12

Bashkimi, Shkoder, Vol. 10, 5 March 1911

Ndocaj F. (1958) Bejtet e karnavaleve , Nentori, Vol. 6, pp.188

Dhamo Dh., et al., pp. 19

Kastrati J. (1970) Kole Idromeno, Jeta e re, Shkodra, 15 August 1970

Shllaku L. , et al.,pp. 135

Paskali O. (1960) Jeta dhe veprat e Kole Arsen Idromenos , Ylli , Vol.8,pp. 10

Paci F. (1974) Elemente realiste ne pikturen e Kole Idromenos e te Simon Rrotes, Shkodra 1974(Annual editorial of Cultural center of Shkodra ), pp. 223

Hudhri F. (1981) Vizatime te Kole Idromenos , Nentori, Vol. 6, pp. 222

Prenushi Gj. (1980) Motra tone, Shqiptarja e Re, Vol. 8, pp. 15

Degrand O., et al.,pp. 279

Gérard G. (1982) Notes on Early Photography in Albania, History of Photography, an international quarterly, Vol. 3, no. 6, pp. 241

Luzati S. (1982) Urbanistika e Idromenos , Zeri i Popullit, 9 May 1982 ,pp.3

Kuqali A. (1980) Kole Idromeno, piktor i shquar i Rilindjes sone Kombetare, Shqiperia e re, Vol. 6, pp.19

Dhamo Dh. (1971) Mbi karakterin kombetar dhe realist te ateve tona figurative , Studime historike, Vol. 2 , pp. 23

Vullneti i popullit , Tirana , 5 July 1931

H. Devolli (1954) Galeria e Arteve te Bashkuara , Nentori, Vol. 2, pp. 152

Nga kronika e ngjarjeve , Nentori, January 1960, Vol. 1, pp.176

Kuqali A. (1960) Un grand peintre albanais , Kole Idromeno (1860-1939) , L'Albanie nouvelle,Vol. 3, pp. 14

Llazari V. (1954) Ekspozita e re e Muzeut te Shkodres, Buletin per shkencat shoqerore, Vol. 1, pp.147 